\title{
Some Notes on the Butterflies of the Cypress Hills
}

\section{by Ronald and Donald Hooper, Somme}

We recently had a very enjoyable holiday trip to the Cypress Hills where we tried to learn more about Saskatchewan butterflies and to add to our own fast-growing butterfly collection.

In two and one-half days we collected 45 species of butterflies in the Cypress Hills, eleven of these being new. to our collection. Forty species were collecited on 'Thursday, June 23, which was an unusually ideal dey for butterfly collecting for the following reasons:

(1) It was a sunny day following a two-day rain. This is an ideal condition for the hatching of iresh butterflies.

(2) It was warm but not too hot.

(3) The wind ives warm and not too strong.

(4) The time was the third week in June which is the height of the butterfly season.

The 11 species new to our collection were as follows:

1. Nevada Fritillary, Argynnis nevadensis Eidw.-1 specimen-to be expected throughout southern Saskatchewan.

2. Hewitson's Checkerspot, Euphydryas anicia Dbldy \& Hew-4 specimens-reported also from Alberta's Cypress Hills.

3. Chalcedon Checkerspot, Euhpydryas chalcedona Dbldy. \& Hew-4 specimens-closest reported rëcord from Missoula, Montana.

4. West Coast Lady, Vanessa carye Hbn.-1 specimen-closest reported record from the Alberta Rockies.

5. Pembina Blue, Plebeius icaroides Bdv.-5 specimens-closest reported record from Big Sandy, Montana, and the Alberta Rockies.

6. Arrow-head Blue, Phaedrotes piasus Scud.-2 specimens-closest reported record from the Alberta Foathills.

7. Baird's Swallowtail, Papilio bairdii Edw.-1 specimen-to be expected throughout southern Saskatchewan.

8. Creusa Marble, Euchlö̈ creusa Dbldy. \& Hew-5 specimens-closest neported record from central Alberta. 9. Palaena Sulphur, Colias palaeno L. - 1 faded specimen-closest re- ported record from the Alberta Rockies.

10. Nastes Sulphur, Colias nastes Bdv.-1 specimen-closest reported record from the Alberta Rockies.

11. Juvenal's Dusky-wing, Erynnis juvenalis Fabr.-4 specimens-to be expected throughout southern Saskatchewan.

Other interesting species collected in the Cypress Hills but not new to us were the Freija Fritillary, Brenthis freija Thun., a species of northern Saskatchewan; Shasta Blue, Plebeius shasta Edw., also taken by us at Eston, Sask.; and Large Marble, Euchloë ausonides Bdv., also taken at Eston and in northern Saskatchewan.

On the same trip we also collected nine species of butterflies at Maple Creek, 15 at Swift Current, and six at Chaplin and Secretan. An interesting record at Swift Current was an Acmon Blue, Plebeius acmon Westwood, which has also been taken by us at Eston.

We hope to be able to return some day to the Cypress Hills for further collections of Rocky Mountain butterflies on Saskatchewan's highest elevations. Our Saskatchewan collection now contains 101 species. We would think there might be $140-150$ species in the province.

It should be kept in mind, that the identification of the specimens reported above was made by ourselves with the help of entomological reference books in our library, and is therefore subject to correction by professional entomologists. The scientific names used in this article are taken from the Check-list of the Lepidoptera of Canada and the United States of America by J. McDunnough (1938). For common names and descriptions we have used the following references: The Butterfly Book (Holland); A Field Guide to the Butterflies of North America, east of the Great Plains (Klots); The Butterfics of Montana (Elrod); Check-list of the Pelidoptera of Alberta (Bowman); The Diurnal Pepidoptera of the Athabasca and Mackenzie Region, British America (Cary). 